\title{
KAJIAN SOSIOLOGI SASTRA DAN PENDIDIKAN KARAKTER DALAM NOVEL NUN PADA SEBUAH CERMIN KARYA AFIFAH AFRA SERTA RELEVANSINYA DENGAN MATERI AJAR DI SMA
}

\author{
Yusuf Muflikh Raharjo', Herman J. Waluyo², Kundharu Saddhono \\ 12 Mahasiswa Program Studi Pendidikan Bahasa Indonesia, \\ Universitas Sebelas Maret, Indonesia \\ E-mail: yusufmuflikhr@gmail.com¹
}

\begin{abstract}
Abstrak
Penelitian ini bertujuan untuk menggambarkan isi novel Nun: In A Mirror oleh Afifah Afra dalam hal literatur studi sosiologi. Novel ini juga memiliki materi pendidikan karakter dan relevansi dengan materi pengajaran di SMA kelas 12, Kurikulum 2013. Novel ini Nun Menceritakan tentang tokoh-tokoh dan masalah hidupnya sebagai aktris Ketoprak dan masalah ekonominya. Penelitian ini adalah penelitian kualitatif dengan pendekatan melalui analisis isi dari studi literatur sosiologi. Hasil penelitian ini adalah bahwa novel Nun: Dalam fenomena Cermin menunjukkan bahwa dekat dengan masyarakat. Novel ini juga Menyediakan unsur seni dan budaya lokal yang Mampu memperkaya budaya pengetahuan orang-orang, terutama bagi siswa. Oleh karena itu, isi dalam novel memiliki potensi untuk digunakan sebagai bahan ajar di kelas SMA 12, sesuai dengan KD 3.1 dan 4.1.
\end{abstract}

Kata Kunci: Sosiologi Sastra, Pendidikan Karakter, Novel

\begin{abstract}
This study aimed to describe the content of the novel Nun: In a Mirror by Afifah Afra in terms of literature sociology. This novel also has a character education materials and relevance to the senior high school teaching material in class 12, 2013. This novel curriculum Nun tells about the characters and the problems of his life as an actress Ketoprak and economic problems. This study is a qualitative research approach through content analysis of literature study sociology. The results of this study is that the novel Nun: In a Mirror phenomenon shows that close to the community. This novel also provide elements of art and local culture are able to enrich the cultural knowledge of the people, especially for students. Therefore, the content of the novel has the potential to be used as teaching material in high school class 12, according to KD 3.1 and 4.1.
\end{abstract}

Keywords: Sociology of Literature, Character Education, Novel

\section{PENDAHULUAN}

Karya sastra sebagai bentuk dan hasil sebuah pekerjaan kreatif, pada dasarnya adalah suatu media yang mendayagunakan bahasa untuk mengungkapkan kehidupan manusia. Sebuah karya sastra, pada umumnya berisi tentang permasalahan yang melingkupi kehidupan manusia. Karya sastra muncul dilatarbelakangi adanya dorongan dasar manusia untuk mengungkapkan eksistensi dirinya
(Sarjidu, 2004). Karya sastra fiksi menceritakan berbagai masalah kehidupan manusia dalam interaksinya dengan diri sendiri, dan interaksinya dengan Tuhan (Nurgiyantoro, 2005). Karya sastra yang dimaksudkan antara lain puisi dan prosa. Melalui kedua jenis karya sastra ini, manusia dapat bercerita kepada orang lain akan kehidupannya dan interaksinya dengan diri sendiri, sesama manusia, atau dengan Tuhannya. Novel sebagai salah satu 
jenis prosa fiksi berperan banyak dalam memberikan pesan-pesan dalam kehidupan karena mayoritas novel mengangkat per-masalahan tentang kehidupan sosial, masyarakat, dan budaya. Hal ini pun diakui oleh Ratna (2007) yang menyatakan bahwa novel dianggap sebagai karya sastra yang paling dominan dalam menampilkan unsur-unsur sosial. Unsur instrinsik akan membahas tentang apa saja yang tekandung di dalam novel seperti alur, tema, plot, latar, setting, tokoh, watak, sudut pandang, dan gaya bahasa. Unsur ekstrinsik dalam sebuah novel adalah unsur-unsur dari luar karya sastra itu secara tidak langsung dapat berpegaruh seperti sosiologi, psikologi filsafat, agama, politik, budaya, dan lainlain (Endraswara, 2008).

Sastra sebagai sebuah teks tidak dapat melepaskan diri dari peran pengarang dan lingkungan terciptanya karya sastra. Elemen-elemen karya sastra, seperti pengarang dan lingkungannya yang terintegrasi dengan budaya yang diangkatnya menjadikan karya sastra dapat dipandang sebagai gambaran sosial masyarakat pada waktu tertentu yang berhubungan dengan masalah sosial. Novel menjadi salah satu karya sastra yang dijadikan sebagai materi ajar di sekolah, khususnya kelas XII Sekolah Menangah Atas. Melaui novel, siswa dapat memetik hal-hal positif yang terkandung dalam novel tersebut sehingga dapat dijadikan sebagai pendidik selain guru. Materi ajar novel secara tersurat dimuat dalam komposisi Kompetensi Dasar (KD) Kurikulum 2013 revisi 2016. Materi tersebut termuat dalam KD 3.1 dan 4.1. KD 3.1 memuat materi yang mengharuskan siswa memenuhi kompetensi dalam mengidentifikasi informasi, yang mencakup orientasi, rangkaian kejadian yang saling berkaitan, komplikasi dan resolusi, dalam cerita sejarah (novel) lisan atau tulis, dan KD 4.1 siswa diharuskan memenuhi kompetensi mengonstruksi nilai-nilai dari informasi cerita sejarah dalam sebuah teks eks-planasi.

Pembelajaran sastra yang sebenarnya bertujuan untuk membangun karakter pada anak didik. Hardiningtyas (2008) menyatakan bahwa pembelajaran sastra bertujuan untuk menanamkan nilai-nilai moral, etika, budi pekerti, dan kemanusiaan pada peserta didik. Pendapat tersebut dipertegas oleh Andayani (2008) bahwa tujuan pembelajaran karya sastra seharusnya dapat mengembangkan kualitas kepribadian siswa, seperti sikap tekun, rajin, ulet, selalu berusaha berbuat baik kepada sesama. Mengacu pendapat tersebut, guru harus dapat mengembang-kan kualitas kepribadian siswa melalui pembelajaran apresiasi novel dari berbagai sumber baik dari cerpen Indonesia, novel terjemahan, maupun novel asing. Oleh sebab itu, pengetahuan, kemampuan, dan wawasan guru perlu diasah. Penguasaan materi tentang karya sastra yang berupa novel pun perlu dikuasai oleh pengajar. Selain itu, para pengajar juga harus memerhatikan kemampuan dalam memilih dan menyajikan materi pembelajaran apresiasi novel pada jenjang SMA.

Seiring dengan bermunculannya novel-novel baru yang sangat signifikan, terdapat beberapa novel yang mengangkat kebudayaan suatu tempat. Salah satu novel tersebut adalah novel Nun: Pada Sebuah Cermin karya Afifah Afra. Novel ini ber-kisahkan tentang seni ketoprak di Kota Surakarta yang semakin kurang diminati oleh masyarakat. Kesenian tradisional, seperti ketoprak, memang kurang digandrungi oleh masyarakat, terutama anak muda. Mereka lebih menyukai budaya populer yang berkembang. Novel Nun: Pada Sebuah Cermin merupakan novel sarat akan budaya. Hal ini ditandai dengan penggunaan alur yang mengacu pada filosofi 11 tembang macapat, yaitu Mijil, Sinom, Mas-kumambang, Asamaradhana, Dhan-dhanggula, Kinanthi, Gambuh, Pangkur, Durma, Pocung, dan Megatruh. Kesebelas temabang macapat melambangkan perjalanan kehidupan manusia dari lahir (Miji) sampai meninggal (Megatruh). Keunikan inilah yang menjadi landasan penulis untuk mengkaji novel ini secara sosiologi sastra, mengingat objek dari 
bahasan novel merupakan situasi sosial yang ada pada sekitar tokoh-tokohnya. Selain itu, penulis juga memiliki tujuan untuk mengenalkan kembali budaya seni ketoprak kepada anak muda, khususnya siswa kelas XII SMA.

\section{METODE}

Penelitian ini merupakan penelitian deskriptif kualitatif dengan pendekatan sosiologi sastra. Novel sebagai karya sastra yang memilki wujud struktural, sosiologi sastra, dan pendidikan karakter yang mampu dikaji secara analisis isi. Melalui triangulasi teori dan narasumber, penelitian ini divalidasi secara komprehensif sehingga mendapatkan data yang benar-benar kredibel. Sosiologi sastra adalah suatu telaah sastra yang objektif dan ilmiah tentang manusia dalam suatu masyrakat yang berkenaan dengan sosial dan proses sosial. Sosiologi menelaah tentang bagaimana masyarakat itu tumbuh dan berkembang dengan baik, dengan mempelajari lembaga-lembaga sosial dan masalah perekonomian, keagamaan, politik, dan lain-lain (Semi, 1993). Apabila sosiologi dan sastra digabungkan, maka hal ini sesuai dengan pendapat Endraswarsa (2003) yang menyebutkan bahwa sosiologi sastra adalah cabang penelitian yang bersifat reflektif. Selanjutnya, Wellek dan Warren (dalam Kurniawan, 2012) membagi tiga paradigma pendekatan dalam sosiologi sastra, yaitu: (1) sosiologi pengarang, yakni memaknai pengarang sebagai bagian dari masyarakat yang telah menciptakan karya sastra, (2) sosiologi karya sastra, yakni analisis terhadap aspek sosial dalam karya sastra dilakukan dalam rangka untuk memahami dan memaknai hubungannya dengan keadaan sosial masyarakat di luarnya, dan (3) sosiologi pembaca, yakni kajian pada sosiologi terhadap pembaca yang memaknai karya sastra dan kajian pada pengaruh sosial yang diciptakan karya sastra. Keseluruhan proses ini tersistem dengan model analisis mengalir (Miles \& Hubberman, 1992). Secara konkret, penelitian ini diawali dengan membaca keseluruhan dari novel Nun: Pada Sebuah Cermin karya Afifah Afra. Setelah membaca dan memahami isi dari novel tersebut, peneliti melanjutkan dengan memilih data dengan cara purposive, yakni memilinnya berdasarkan pada pertimbangan dari fokus penelitian sosiologi sastra ini, antara lain unsur intrinsik, ekstrinsik, dan implikasinya di masyarakat dari novel tersebut. Selanjutnya, melalui sumber data juga yang berupa informan diperoleh data sekunder yang memperkaya data dalam penelitian ini.

Uji validitas dalam penelitian ini dilakukan dengan tiga triangulasi. Ketiga triangulasi tersebut antara lain: (1) triangulasi teori; (2) triangulasi sumber data; dan (3) triangulasi peneliti. Melalui langkah uji validitas tersebut peneliti bisa lebih mudah untuk mendapatkan data dan kesahihan antarteori sebagai acuan penelitian. Triangulasi sumber data adalah teknik untuk menyelaraskan kebenaran data hasil analisis dengan wawancara sumber yang berbeda, tetapi membahas hal yang sama.

\section{HASIL DAN PEMBAHASAN}

Kajian sosiologi sastra dikenalkan pada era 1970-an sampai 1980-an (Singer, 2011). Dalam tulisannya, dideskripsikan bahwa kajian ini secara kronologis ditunjukkan oleh Griswold yang menyatakan bahwa kajian sosiologi sastra seperti amoeba, tidak memiliki struktur yang pasti tetapi dapat dikaitkan dengan apapun (Griswold, 1992). Sedangkan, kajian sosiologi sastra merupakan cabang penelitian sastra yang bersifat reflektif. Penelitian ini banyak diminati oleh peneliti yang ingin melihat sastra sebagai cermin kehidupan masyarakat (Suwardi, 2008). Pendapat tersebut memperkuat pendapat peneliti yang berhubungan dengan kajian sosiologi sastra, kajian sosiologi sastra pada dasarnya akan mempelajari tentang kajian yang terdapat dalam masyrakat dan lingkungan sekitarnya. Pernyataan tersebut diperkuat dengan pendapat milik Damono (1979) yang menyatakan salah satu pendekatan dalam kajian sastra yang memahami dan menilai 


$\begin{array}{lrr}\text { karya sastra } & \text { dengan } \\ \text { mempertimbangkan } & \text { segi-segi } \\ \text { kemasyarakatan } & \text { (sosial). Tujuan studi } \\ \text { atau kajian } & \text { sosiologi } & \text { dalam } \\ \text { kesusastraan } & \text { adalah } & \text { untuk }\end{array}$
mendapatkan gambaran utuh mengenai hubungan antara pengarang, karya sastra, dan masyarakat (Pradopo, 1993). Hal ini berarti menunjukkan bahwa kajian sosiologi sastra menjadi sebuah kajian yang memiliki ranah luas untuk mengkaji sebuah karya sastra. Karya sastra yang berupa puisi maupun prosa tentu memiliki keterkaitan dengan masyarakat sehingga poin-poin yang ada di dalamnya pun dapat berimplikasi kepada masyarakat. Sosiologi sastra menjadi landasan teori yang menganalisis masalah yang menyangkut hubungan antara sastra dengan masyarakat. Sosiologi berusaha menjawab pertanyaan mengenai bagaimana masyarakat dimungkinkan, bagaimana cara kerjanya, dan mengapa masyarakat itu bertahan hidup.

Swingewood (dalam Wiyatmi, 2008) menguraikan bahwa sosiologi merupakan studi ilmiah dan objektif mengenai manusia dalam masyarakat, studi mengenai lembaga-lembaga dan proses sosial. Bentuk umum proses sosial adalah interaksi sosial, yang merupakan syarat utama terjadinya aktivitas-aktivitas sosial, khususnya dari interaksi sosial. Interaksi sosial merupakan hubungan-hubungan sosial yang dinamis yang menyangkut hubungan antara orang perorangan, antara kelompok-kelompok manusia, maupun antara orang perorangan dengan kelompok manusia (Soekanto, 1982). Analisis sosiologi sastra tidak dapat dipisahkan dari analisis struktur, hal ini dikarenakan karya sastra merupakan struktur yang bermakna. Karya sastra dalam pendekatan sosiologi sastra pada dasarnya berawal pada dua titik tumpu penelahaan. Titik tumpu yang pertama beranggapan bahwa teks sastra merupakan subjek dalam kerja analisis yang berupa pemahaman tentang struktur. Titik tumpu yang kedua adalah anggapan bahwa sastra merupakan cermin proses interaksi sosial. Baik sosiologi maupun sastra memiliki objek kajian yang sama, yaitu manusia dalam masyarakat, memahami hubungan-hubungan antarmanusia dan proses yang timbal dari hubungan-hubungan tersebut di dalam masyarakat. Sosiologi dan sastra memiliki objek yang sama, yaitu sastra dalam masyarakat, tetapi pada hakikatnya antara sosiologi dan sastra memiliki perbedaan, sosiologi hanya membatasi diri pada apa yang terjadi dewasa ini, bukan apa yang seharusnya terjadi, sedangkan sastra lebih bersifat evaluatif, subjektif, dan imajinatif (Ratna, 2003).

Dari kutipan tersebut dapat disimpulkan bahwa sosiologi dan sastra selalu berhubungan dengan masyarakat. Istilah sosiologi sastra diterapkan pada tulisan-tulisan para kritikus dan ahli sejarah sastra yang perhatian utamanya ditujukan pada cara-cara bagaimana seorang pengarang dipengaruhi oleh status kelasnya, ideologi masyarakat, keadaan-keadaan ekonomi yang berhubungan dengan pekerjaannya dan jenis pembaca yang dituju (Abrams, 1981). Goldmann mengembangkan sosiologi sastra untuk menyatukan analisis struktural dengan matrealisme historis dan dialektik. Karya sastra harus dipahami sebagai totalitas yang bermakna. Karya utama sastra dan filsafat memiliki kepaduan total dan unsur-unsur yang membentuk teks mengandung arti apabila dapat memberikan suatu lukisan lengkap dan padu tentang makna. Dalam hal ini sastra adalah fakta-fakta yang mempunyai kedudukan yang sama seperti dalam penelitian ilmiah yang dipelopori oleh Hippolyte Taine. Pandangan ini mengatakan bahwa sastra bukanlah sekedar pencerminan masyarakatnya, sastra merupakan usaha manusia untuk menemukan makna dunia atas nilai-nilai yang terkandung di dalamnya. Nilai-nilai itu harus dihayati oleh orang dan masyarakat (Faruk, 2010). Sosiologi dan sastra memiliki objek yang sama yaitu sastra dalam masyarakat, tetapi pada hakikatnya antara sosiologi dan sastra memiliki perbedaan, sosiologi 
hanya membatasi diri pada apa yang terjadi dewasa ini, bukan apa yang seharusnya terjadi, sedangkan sastra lebih bersifat evaluatif, subjektif, dan imajinatif (Ratna, 2003). Dari kutipan tersebut dapat disimpulkan bahwa sosiologi dan sastra selalu berhubungan dengan masyarakat. Istilah sosiologi sastra diterapkan pada tulisan-tulisan para kritikus dan ahli sejarah sastra yang perhatian utamanya ditujukan pada cara-cara bagaimana seorang pengarang dipengaruhi oleh status kelasnya, ideologi masyarakat, keadaan-keadaan ekonomi yang berhubungan dengan pekerjaannya dan jenis pembaca yang dituju (Abrams, 1981). Goldmann mengembangkan sosiologi sastra untuk menyatukan analisis struktural dengan matrealisme historis dan dialektik. Karya sastra harus dipahami sebagai totalitas yang bermakna. Karya utama sastra dan filsafat memiliki kepaduan total dan unsur-unsur yang membentuk teks mengandung arti apabila dapat memberikan suatu lukisan lengkap dan padu tentang makna.

Dalam hal ini sastra adalah faktafakta yang mempunyai kedudukan yang sama seperti dalam penelitian ilmiah yang dipelopori oleh Hippolyte Taine. Pandangan ini mengatakan bahwa sastra bukanlah sekedar pencerminan masyarakatnya, sastra merupakan usaha manusia untuk menemukan makna dunia atas nilai-nilai yang terkandung di dalamnya. Nilai-nilai itu harus dihayati oleh orang dan masyarakat (Faruk, 2010). Swingewood (1972) membagi sosiologi sastra atas empat bagian; (1) sosiologi dan sastra: pendekatan yang dapat dilakukan dalam hal ini melihat karya sastra sebagai dokumen budaya yang mencerminkan suatu zaman, kedudukan seorang penulis dan penerimaan suatu karya dari penulis tertentu; (2) teori-teori sosial tentang sastra: pendekatan dilakukan dengan teori Hippolyte Taine, teori Marxist dan latar belakang suatu karya; (3) sastra dan strukturalisme: pendekatan yang menghubungkan formalime Rusia dan aliran linguistik Praha disebut sebagai strukturalisme genetik dari Lucien Goldmann; dan (4) persoalan metode: pendekatan positivisme, karya dianggap sebagai dokumen yang mencatat unsur sosiobudaya dan dialektik, unsur budaya dalam suatu karya bukanlah setiap unsurnya, tetapi keseluruhannya yang merupakan kesatuan.

Sosiologi merupakan ilmu pengetahuan kemasyarakatan umum yang merupakan hasil terakhir daripada perkembangan ilmu pengetahuan. Sosiologi lahir pada saat-saat terakhir perkembangan ilmu pengetahuan. Oleh karena sosiologi didasarkan pada kemajuan-kemajuan yang telah dicapai ilmu-ilmu pengetahuan lainnya. Sosiologi sebagai studi yang ilmiah dan objektif mengenai manusia dalam masyarakat, studi mengenai lembagalembaga dan proses-proses sosial. Sosiologi berusaha menjawab pertanyaan mengenai masyarakat dimungkinkan, bagaimana carakerjanya dan mengapa masyarakat itu bertahan hidup. Gambaran ini akan menjelaskan cara-cara manusia menyesuaiakan diri dengan ditentukan oleh masyarakatmasyarakat tertentu, gambaran mengenai mekanisme sosialisasi, proses belajar secara kultural, yang dengannya individu-individu dialokasikan pada dan menerima peranan-peranan tertentu dalam strutur sosial. Di samping itu sosiologi juga menyangkut menangani perubahanperubahan sosial yang terjadi secara berangsur-angsur maupun secara revolusioner dengan akibat-akibat yang ditimbulkan oleh perubahan tersebut (Damono, 1978). Salah satu karya sastra yang dapat dikaji dengan sosiologi sastra adalah novel. Griswold (2000) telah mengeksplorasi dampak produksi sistem pada isi karya sastra. Kajian sosiologi sastra yang telah dilakukan di berbagai negara, khususnya Indonesia juga telah banyak dilakukan untuk membuktikan pernyataan Griswold. Griswold sendiri telah melakukan penelitian yang menganalisis dari novel-novel terbitan Inggris dan Nigeria yang mana banyak mengambil tema tradisional dan urban. Dijelaskan lebih lanjut bahwa hasil dari 
penelitian Griswold menunjukkan rakyat Nigeria banyak digambarkan selalu berjuang untuk menghadapi masalahmasalah modernitas (Singer, 2011).

Penelitian lain yang berkaitan dengan Griswold juga telah dilakukan oleh Purwaningtyastuti (2013). Penelitian ini mengkaji novel-novel Indonesia yang ditulis oleh pengarang perempuan ditinjau dari perspektif gender, pendidikan, dan tentu saja sosiologi sastra. Penelitian Purwaningtyastuti ini menunjukkan bahwa fenomena kesetaraan gender antara laki-laki dan perempuan memang menjadi hal yang sudah tidak asing di Indonesia. Banyak perempuan yang saat ini menjadi tulang punggung keluarga karena berbagai alasan yang melatarbelakanginya. Dikuatkan dengan penulis yang juga seorang perempuan otomatis novel-novel ini dinilai sangat dekat dengan kondisi yang ada dan sebenarnya. Dengan demikian bahwa karya sastra berupa novel memang sangat dekat dengan masyarakat, baik kondisi, situasi, dan setingnya. Tulisan ini merupakan pengkajian sebuah karya sastra berupa novel dengan pendekatan sosiologi sastra karena pendekatan sosiologis menganggap karya sastra sebagai milik masyarakat (Ratna, 2015). Penelitian Asri (2011) mengungkap relevansi sastra dengan kehidupan masyarakat. Sejauh mana sastra dapat mencerminkan kondisi masyarakat.

Penelitian Asri menyatakan jika semakin tinggi tingkat kerelevanan sosial-budaya masyarakat dalam karya sastra dengan realitas sosial-budaya masyarakat, maka semakin bermutu karya sastra tersebut. Begitupun sebaliknya. Hal tersebut ditegaskan oleh Ratna (2015) menyatakan bahwa pendekatan sosiologis sastra menganggap karya sastra itu milik masyarakat sehingga terjadi kaitan hakiki antara karya sastra dengan masyarakat. Kaitannya berupa: a) karya sastra dihasilkan oleh pengarang; b) pengarang itu sendiri adalah anggota masyarakat; c) pengarang memanfaatkan kekayaan dalam masyarakat; hasil karya sastra itu dimanfaatkan kembali oleh masyarakat. Nurgiyantoro (2005) mengatakan, unsur intrinsik adalah unsur yang secara langsung membangun karya sastra. Unsur ini meliputi peristiwa, cerita, plot, penokohan, tema, latar, sudut pandang penceritaan dan gaya bahasa. Sedangkan unsur ekstrinsik adalah unsur-unsur yang berada di luar karya sastra, tetapi secara tidak langsung mempengaruhi bangun atau sistem karya sastra.

A. Teeuw (dalam Waluyo, 2002) berpendapat, sebuah sistem sastra memiliki tiga aspek: pertama eksternestrukturrelation, yaitu struktur yang terikat oleh sistem bahasa pengarang terikat oleh bahasa yang dipakainya; kedua interne strukturrelation, yaitu struktur dalam yang bagian-bagiannya saling menentukan dan saling berkaitan, dan ketiga model dunia sekunder, yaitu model dunia yang dibangun oleh pengarang, dunia fantasi atau dunia imajinasi. Untuk dapat memahami sebuah karya sastra, khususnya cerpen, maka perlu dibedah struktur yang dimiliki cerpen tersebut. Novel Nun: Pada Sebuah Cermin (NPSC) merupakan novel yang sarat akan nilai budaya, yakni budaya Jawa. Budaya Jawa yang disurat dan disiratkan berupa kesenian ketoprak dan filosofi sebelas tembang macapat. Novel ini dikarang oleh pengarang yang juga orang Jawa, yang bernama Afifah Afra. Keseluruhan kajian dalam tulisan ini akan dibahas secara perinci, dengan fokus bahasan latar belakang pengarang., struktur intrinsik novel, nilai pendidikan karakter, relevansi dengan materi ajar di SMA, dan aspek sosio-budaya.

Afifah Afra merupakan seorang pengarang novel yang memiliki latar belakang sebagai pegiat literasi. Berperan menjadi seorang CEO dari sebuah penerbit di Kota Surakarta, Afifah Afra sudah banyak menghasilkan novel-novel yang sarat dengan nilai edukatif. Afifah Afra memiliki nama asli Yeni Mulati Sucipto. Wanita kelahiran Purbalingga, 18 Februari 1979 ini memang sudah memiliki hasrat yang kuat untuk mendedikasikan dirinya 
untuk membudayakan literasi. Khazanah Afra dalam hal literasi dapat dinilai cukup banyak. Hal ini dibuktikan dengan perolehan penghargaan dari beberapa pihak atas tulisan-tulisannya. Selain itu, karier literasinya sudah terasah saat berkecimpung dalam Forum Lingkar Pena (FLP). Novel NPSC menjadi salah satu karya Afra yang tergolong berani dalam membedah sebuah fakta yang ada dalam sebuah lingkungan di sekitar terminal. Tokoh Nun dalam novel merupakan seorang perempuan belia tinggal di sekitar terminal di Kota Surakarta. Dalam cerita Afra, Nun menjadi seorang pemain ketoprak. Kehidupan Nun menjadi potret kehidupan yang nyata. Melalui novel ini, Afra telah menunjukkan realitas yang terjadi dalam kehidupan masyarakat di sekitar terminal dan seorang pemain ketoprak.

Adapun unsur-unsur yang membangun karya fiksi secara garis besar dibagi menjadi dua bagian, yaitu (1) struktur luar (ekstrinsik) dan (2) struktur dalam (intrinsik). Pendapat yang sama dipaparkan Nurgiyantoro (2005), karya sastra mengandung unsur intrinsik dan unsur ekstrinsik selain unsur formal bahasa yang selanjutnya hal ini dikenal dengan pendekatan strukturalisme genetik, yakni pendekatan yang memberikan perhatian terhadap analisis intrinsik dan ekstrinsik (Ratna, 2015). Semi (1993) menyatakan, struktur luar (ekstrinsik) adalah segala macam unsur yang berada di luar suatu karya sastra yang ikut mempengaruhi kehadiran karya satra tersebut, misalnya faktor sosial, faktor ekonomi, faktor kebudayaan, faktor sosial politik, faktor keagamaan dan tata nilai yang dianut masyarakat. Struktur dalam (intrinsik) adalah unsurunsur yang membentuk karya sastra tersebut seperti penokohan (perwatakan), tema, alur (plot), pusat pengisahan, latar dan gaya bahasa. Struktur novel dalam tulisan ini dimaksudkan dalam pembahasan struktur intrinsik novel yang diambil dari bagian pendekatan strukturalisme genetik. Strukturalisme genetik dalam karya sastra meliputi unsur intrinsik dan ekstrinsik novel yang dikaitkan dengan situasi sosial yang ada dalam novel (Ratna, 2015). Struktur novel ini nanti berfokus pada tema, alur, seting tempat, tokoh, dan penokohan.

Novel NPSC bertemakan tentang kehidupan sosial masyarakat khususnya pada fragmen potret orang marginal. Marginal dalam hal ini diartikan bertempat tinggal di lingkungan terminal yang berkecenderungan memiliki kondisi sosial yang keras. Afra sebagai pengarang mengemas novel ini dengan baik yang ditunjukkan dengan menunjukkan kegigihan seorang perempuan yang masih muda belia dalam mengarungi kerasnya kehidupan. Nun harus bekerja sebagai pemain ketoprak untuk membantu orangtuanya dalam mencari nafkah. Selain itu, kegelisahan Nun akan kondisi asmaranya yang terkendala dengan tokoh Mas Wiratno yang notabene seorang laki-laki yang sudah berusia jauh lebih tua dari Nun. Nun harus bekerja tiap malam untuk mementaskan sebuah pertunjukan ketoprak. Meski menjadi seorang yang diidolakan, Nun memiliki permasalahan atas upah yang diterimanya yang dinilai masih kurang dari cukup. Namun karena ia menyadari atas keterbatasannya dalam keterampilan, akhirnya hal ini pun menjadi pemakluman baginya. Permaslahan asmara dengan Mas Wir juga turut mewarnai dalam tema novel NPSC. Nun yang tergolong perempuan remaja yang secara psikologis tengah mengalami masa puber dihadapkan dengan jatuh hati dengan seorang pria yang berusia terpaut jauh darinya. Hal ini menjadi kegelisahan bagi Nun karena Mas Wir merupakan lawan main dalam bermain ketoprak yang selalu memerankan sebagai kekasih Nun dalam panggung.

Alur dalam novel NPSC adalah alur progresif. Namun, terdapat keunikan dalam pengemasan alur ini. Afra menggunakan filosofi sebelas tembang macapat dalam alur novel ini. Sebelas tembang tersebut antara lain Mijil, Sinom, Maskumambang, Asmaradhana, Dhandhanggula, Durma, Pangkur, Gambuh, Pocung, Megatruh, 
Kinanthi. Mijil menjadi awal dalam alur novel ini. Mijil memiliki arti awalan atau lahir dalam bahasa Jawa yang dalam novel ini dianalogikan dengan pengenalan tokoh dan awal munculnya konflik-konflik yang akan dipertunjukkan dalam novel. Sinom berarti masa muda, yakni diartikan sebagai masa muda Nun yang notabene perempuan remaja yang sedang mengalami permasalahanpermasalahan layaknya seorang remaja, yakni asmara. Maskumambang dalam novel menceritakan tentang ayah tiri Nun yang bernama Pak Jiwo. Pak Jiwo memiliki watak yang keras, sering melakukan kekerasan kepada ibu dan Nun serta dikenal sering meresahkan warga sekitar. Asmaradhana menjadi posisi di mana tokoh Nun mulai mengalami kerumitan dalam kisah asmaranya, antara dengan Mas Wir dan Naya. Pada tahapan ini, Nun merasa sangat mungkin untuk dekat dengan Naya karena untuk membangun sebuah hubungan tidak mementingkan harta atau rupa, tetapi hati. Dhandhanggula menunjukkan masa manis dalam kehidupan Nun, yakni tengah menemukan kenyamanan antara kisah hidup dan asmaranya. Durma menjadi proses Nun mulai mendalami kehidupan yang berasal dari Tuhan. Dia mulai diberikan pengertian-pengertian tentang kehidupan itu sejatinya harus selalu bergantung pada Sang Maha Pencipta. Pangkur menjadi sebuah alur sedih dalam novel ini. Pada proses ini diceritakan bahwa ibu Nun telah meninggal tertimbun sampah di TPS Putri Cempo. Nun sangat terpukul akan peristiwa ini.

Diceritakan bahwa seorang orangtua, dalam hal ini ibu Nun, sangat sayang kepada Nun dengan ditunjukkan didikannya kepada anaknya yang penuh kasih sayang. Gambuh menjadi lanjutan dari Pangkur yang ditunjukkan dengan Nun memutar kembali ingatannya akan sosok ibunya yang senantiasa memberikan dukungan lahir dan batin dalam kehidupannya. Pocung dan Megatruh melukiskan kisah kehidupan Nun dalam cerita yang mulai mengalami keputusasaan, di mana Nun merasa telah kehilangan semangat dalam menjalani hidup karena beberapa orang yang disayanginya, termasuk ibunya yang telah meninggal. Dia pun merasa sudah tidak ada artinya dalam hidup. Namun, pada posisi Kinanthi, Nun akhirnya menemukan kembali jalan hidupnya setelah ia dapat berintrospeksi dan mengambil hikmah dari persoalanpersoalan hidup yang menimpanya. Akhirnya, Nun pun mulai dapat menemukan kembali irama kehidupannya setelah dipinang oleh pujaan hatinya, Mas Wir. Keseluruhan Macapat dalam alur novel ini menggambarkan bahwa fase kehidupan seorang manusia tidak berakhir saat menjadi pocong, tetapi setelah itu ada proses pisahnya roh dengan raga manusia serta menanti balasan atas amalan yang dibawa untuk bekal akhiratnya (Supajar dalam Afra, 2015). Novel NPSC memiliki seting tempat dan suasana yang dominan muncul. Setting tempat dalam novel ini berlokasi di Kota Surakarta, meliputi gedung ketoprak, permukiman sekitar terminal, dan gedung pertunjukan Taman Budaya Jawa Tengah. Sedangkan seting suasana kerap dimunculkan adalah suasana kegelisahan dan kasmaran yang dialami Nun.

Novel NPSC memiliki tokoh utama yang bernama Nun Walqolami. Nun ini memiliki watak yang gigih dalam menghadapi persoalan kehidupannya sebagai seorang perempuan remaja. Nun dikisahkan menjadi seorang pemain ketoprak yang harus tampil tiap malam untuk membantu dalam mencari nafkah. Selain itu, Nun juga dihadapkan pada persoalan percintaan dirinya dengan Mas Wir dan juga Naya. Namun, pada akhirnya Nun pun menikah dengan Mas Wir, sesosok pria dambaan hati Nun yang berusia lebih tua darinya. Tokoh lain dalam novel ini antara lain Mas Wir dan Naya. Mas Wir dan Naya memiliki peran sebagai tokoh yang memunculkan konflik dalam cerita. Mas Wir memiliki watak penyayang kepada Nun. Dia selalu menjadi sosok yang dewasa bagi Nun dan sering membantu dalam memecahkan permasalahan Nun. Sedangkan Naya adalah pemuda yang berwatak kurang baik karena telah 
mempermainkan hati Nun. Nun yang sebenarnya telah menyadari bahwa tidak mungkin dia akan bersanding dengan Naya, seorang yang berbeda kelas dengannya. Namun, perhatian Naya kepada Nun akhirnya membuat Nun optimis dapat bersanding dengannya. Akan tetapi, hal ini akhirnya pupus dikarenakan Naya harus menuruti kemauan dari ayahnya untuk tidak menikah dengan Nun.Pendidikan karakter merupakan sebuah gerakan yang selalu didengungkan sejak awal 2010 silam. Pendidikan karakter kemudian disambut sangat baik ditandai dengan adanya kajian-kajian yang membahas tentang muatan karakter dalam suatu hal, salah satunya adalah karya sastra novel. Novel yang merupakan sebuah karya sastra kompleks sangat dimungkinkan memuat banyak nilai karakter, yang tentu saja baik untuk pembaca. Nilai karakter tersebut antara lain jujur, tanggung jawab, disiplin, dan berjiwa kuat.

Pendidikan dan sastra merupakan hal yang tidak bisa lepas dalam pembelajaran dengan berbagai metode yang digunakan sebagai media. Media tersebut dibuat semenarik mungkin dan penuh kreativitas agar manusia lebih berminat untuk mengikuti media tersebut. Karena dengan hasil yang diinginkan dapat mengembangkan kreativitas seseorang dalam hidupnya. Salah satu media yang dapat memberikan dampak positif bagi pendidikan adalah melalui media sastra. Teeuw (1984) berpendapat, pada hakikatnya kata sastra sendiri berasal dari bahasa Sansekerta, akar kata sasdalam kata kerja turunan berarti mengarahkan, memberi petunjuk, dan instruksi. Sedangkan akhiran -tra berarti menunjukkan alat atau sarana. Novel merupakan karangan prosa panjang yang mengandung rangkaian cerita kehidupan seseorang dengan orang disekitarnya, yang melukiskan perbuatan-perbuatan pelakunya menurut watak isi jiwa masing-masing dengan berbagai nilai yang terkandung. Nilai mengungkapkan perbuatan apa yang dipuji dan dicela, pandangan hidup mana yang dianut dan dijauhi, dan hal apa saja yang dijunjung tinggi. Adapun nilai-nilai pendidikan yang terdapat dalam novel, di antaranya nilai religius, moral, sosial, dan budaya.

Novel NPSC merupakan novel yang dinilai dapat memberikan sumbangsih sebagai materi ajar dalam mata pelajaran bahasa Indonesia di SMA karena memilki nilai-nilai pendidikan yang cukup banyak. Dalam Pedoman Pelaksanaan Pendidikan Karakter (2011) disebutkan bahwa strategi pelaksanaan pendidikan karakter di satuan pendidikan merupakan satu kesatuan dari program manajemen peningkatan mutu berbasis sekolah yang terimplementasikan dalam pengembangan, pelaksanaan dan evaluasi kurikulum oleh setiap satuan pendidikan. Nilai-nilai pendidikan tersebut dimunculkan oleh tokoh Nun yang kerap bijak dalam menghadapi suatu persoalan dalam kehidupan. Tokoh utama dalam novel ini juga memberikan pelajaran penting bahwa kehidupan harus selalu berpegang teguh dengan tuntunan agama dan nasihat-nasihat dari orangtua. Selain itu, Nun juga memiliki sifat menghormati dan menghargai orang yang lebih tua dan senior dari dirinya yang ditunjukkan dari penggunaan bahasa dan tingkah laku yang selalu andhap asor.

Perilaku sosial terhadap masyarakat di sekitarnya pun juga baik, hal ini ditunjukkan dengan banyak yang menaruh simpati bahkan empati kepada dirinya dan keluarganya. Sedangkan aspek sosio-budaya dalam novel ini ditunjukkan pada watak Nun yang mencerminkan sosok perempuan Jawa. Selain itu, adanya nilai nguri-nguri budaya Jawa berupa kesenian ketoprak juga dijadikan salah satu bahasan dalam novel. Hal ini tentu saja secara langsung maupun tidak langsugn memberikan informasi atau ajakan kepada pembaca untuk kembali atau hanya sekadar mengenali budaya lokal, kesenian ketoprak, lengkap dengan segala bentuk lika-likunya.

Novel NPSC sangat memiliki potensi untuk dijadikan sebagai materi ajar. Kesesuaian materi ajar untuk novel ini dapat diterapkan pada salah satu 
materi untuk siswa kelas XII sekolah menengah atas. Materi ajar novel secara tersurat dimuat dalam komposisi kompetensi dasar (KD) Kurikulum 2013 revisi 2016. Materi tersebut termuat dalam KD 3.1 dan 4.1. KD 3.1 memuat materi yang mengharuskan siswa memenuhi kompetensi dalam mengidentifikasi informasi, yang mencakup orientasi, rangkaian kejadian yang saling berkaitan, komplikasi dan resolusi, dalam cerita sejarah (novel) lisan atau tulis, dan KD 4.1 siswa diharuskan memenuhi kompetensi mengonstruksi nilai-nilai dari informasi cerita sejarah dalam sebuah teks eksplanasi. Hal yang dapat diambil sebagai implikasi dari novel ini tidak lain dari segi nilai-nilai pendidikan karakter yang ada dalam novel.

Secara garis besar, implikasi novel NPSC dengan pembelajaran di SMA adalah nilai-nilai kehidupan yang ada dalam novel dinilai dekat dengan siswa, terutama bagi siswa yang berdomisili di Kota Surakarta. Kedekatan itu terletak dalam hal kehidupan yang mana setiap manusia sejak dini harus pandai dalam mengambil hikmah dari sebuah peristiwa. Bentuk-bentuk permasalahan yang dimunculkan dalam novel NPSC juga telah disertai bagaimana cara mengatasinya sehingga pembaca juga telah diberikan sebuah jalan untuk menyelesaikan suatu persoalan dalam kehidupan. Selain itu, siswa SMA yang tergolong remaja juga perlu diberikan pemahaman terhadap kesenian dan kebudayaan lokal yang ada, yakni ketoprak dan filosofi sebelas tembang macapat. Saat ini masih banyak siswa SMA yang belum mengenali kedua hal ini sehingga perlu diberikan materi ajar yang tepat melalui novel, salah satunya.

\section{SIMPULAN DAN SARAN}

Novel NPSC merupakan novel yang sarat akan aspek sosio-budaya dan pendidikan karakter. Hal ini dapat ditunjukkan dari unsur-unsur intrinsik dan ekstrinsik yang terdapat dalam novel, yang dalam hal ini dikaji dengan pendekatan strukturalisme genetik. Kesatuan kajian ini yang akhirnya menjadi kajian sosiologi sastra menghasilkan bahwa novel NPSC memiliki potensi untuk dijadikan sebagai materi ajar karena muatan-muatan aspek sosio-budaya dan nilai pendidikan karakternya dapat diambil sebagai wujud implikasi dari sebuah karya sastra yang notabene dari masyarakat kemudian dikembalikan manfaatnya juga kepada masyarakat.

\section{DAFTAR PUSTAKA}

A, T. (1984). Sastra dan Ilmu Sastra: Pengantar Teori Sastra. Bandung: Pustaka Jaya.

Afra, A. (2015). Nun: Pada Sebuah Cermin. Jakarta: Republika.

Asri, Y. (2011). Analisis Sosiologis Cerpen Si Padang Karya Ardini Pangastuti B. Jurnal Humaniora, 23((3)), 245-255.

Damono, S. D. (1978). Sosiologi Sastra Sebuah Pengantar Ringkas. Jakarta: Pusat Pembinaan dan Pengembangan

Bahasa Depdikbud.

Damono, S. D. (1979). Sosiologi Sastra Sebuah Pengantar Ringkas.

Faruk. (2010). Pengantar Sosiologi Sastra. Yogyakarta: Pustaka Pelajar.

Griswold, W. (1992). The writing on the Mud Wall: Nigerian Novels and the Imaginary Village. American Sociological Review, 57(6), 709724.

https://doi.org/10.2307/2096118

Griswold, W. (2000). Bearing Witness: Readers, Writers, and the Novel in Nigeria. Princeton: $\mathrm{NJ}$ : PrincetonUniversity Press. https://doi.org/10.2307/525635

Kurniawan, H. (2012). Teori, Metode, dan Aplikasi Sosiologi Sastra. Yogyakarta.: Graha IImu.

Miles, M dan Hubberman, A. M. (1992). Analisis Data Kualitatif. UI Press. Jakarta: UI Press. 
Norton, D. S., Rushton, P., \& Abrams, M. H. (1981). A Glossary of Literary Terms. Holt, Rinehart et Winston, inc. (Vol. 8). New York: Holt, Rinehart et Winston, inc. https://doi.org/10.2307/354930

Nurgiantoro, B. (2005). Teori Pengkajian Fiksi. Yogyakarta: Gadjah Mada University Press.

Padmadewi, N. N. (2015). Pengembangan Perangkat Pembelajaran Berbasis Pendidikan Karakter Untuk Mata Kuliah Strategi Pembelajaran Bahasa Jurusan Pendidikan Bahasa Jepang Di Universitas Pendidikan Ganesha Singaraja. Jurnal Pendidikan Indonesia Universitas Pendidikan Ganesha. Volume 4 (1) Retrieved from http://ejournal.undiksha.ac.id/index .php/JPI/article/viewFile/4893/36 86.\%0A

Pradopo, R. D. (1993). Pengkajian Puisi. Yogyakarta: Gadjah Mada University Press. Retrieved from http://scholar.google.com/scholar? $\mathrm{q}=$ pradopo\&btnG=\&hl=id\&as_sdt= $0 \% 2 \mathrm{C} 5 \# 0$

Purwaningtyastuti, R. (2013). Novels Works of Women Authors Indonesia of 2000's (Sociology Study of Literature, Gender Prespectives, and Educational Value)". Journal of Education and Practice, 4 (18), 107-114.

Ratna, N. K. (2015). Teori, Metode, dan Teknik Penelitian Sastra. Yogyakarta: Pustaka pelajar.

Saddhono, K. dan Rohmadi, M. (2014). A Sociolinguistic Study on the Use of the Javanese Language in the Learning Process. International Education Studies, 7(6), 25-30. Retrieved from http://sfX.scholarsportal.info/guelph /docview/1026924496? accountid= 11233\%5Cnhttp://sfx.scholarsport al.info/guelph?url_ver=Z39.882004\&rft_val_fmt=info:ofi/fmt:kev: $m t x:$ dissertation\&genre $=$ dissertatio ns+\%26+theses\&sid=ProQ:ProQu est+Dissertations+\%26+Theses+A

Saddhono, K., \& Supeni, S. (2014). The role of dutch colonialism in the political life of Mataram dynasty: A case study of the manuscript of Babad Tanah Jawi. Asian Social Science.

https://doi.org/10.5539/ass.v10n15 p1

Semi, M. A. (1993). Anatomi Sastra. Anatomi Sastra. Padang: Angkasa Raya.

Singer, A. E. (2011). A Novel Approach: The Sociology of Literature, Children's Books, and Social Inequality. International Journal of Qualitative Methods. https://doi.org/10.1177/160940691 101000401

Swingewood, A., dan D. L. (1972). The Sociology of Literature. Paladine.

Waluyo, H. J. (2002). Apresiasi Puisi. Jakarta: Gramedia Pustaka Utama.

Waluyo, H. J. (2017). Aksara, 2(1), 116. 